\title{
POLITICAL PRAGMATISM AND ETHICS IN KAUTYLA'S ARTHASHASTRA: CONTRADICTION OR COMPLEMENTARITY
}

\author{
PRAGMATISMO POLÍTICO E ÉTICA NO ARTHASHASTRA DE \\ KAUTYLA: CONTRADIÇÃO OU COMPLEMENTARIDADE
}

\author{
Shreya Bhattacharya* \\ shreya.bhattacharya@politics.ox.ac.uk \\ Kankana Saikia** \\ kankana_saikia@yahoo.in
}

\begin{abstract}
Is there always an inherent contradiction between political pragmatism and ethics? This paper explores this through the classical Indian realist political treatise, the Arthashastra, written by Kautilya. He was the key advisor to Emperor Chandragupta Maurya (c. 317-293 B.C.E), credited with first consolidating the Indian subcontinent into an empire under centralized control. Kautilya is widely agreed to be a pioneer in developing a 'science of politics'- a great departure from the hitherto existing moralistic, spiritual, ascetic preoccupations and, religious speculations of Indian political philosophy. Kautilya blurred the distinction between morality and political utility. Much of political theory tradition remains oblivious to Kautilya's contribution to morality in realpolitik and his continuing influence in non-Western societies. His treatise is a significant point of entry into exploring the dilemmas attached to active pursuance of ethical goals while also balancing the imperatives underpinning political pragmatism- a concern which has carried on to this day.
\end{abstract}

Keywords: political pragmatism, morality, means, ends, Arthashastra.

Sumário. Haverá sempre uma contradição intrínseca entre o pragmatismo político e a ética? Este artigo explora este tema através do realismo do tratado político clássico indiano, o Arthashastra, escrito por Kautyla. Ele era o conselheiro principal do Imperador Chandragupta Maurya (c. 317-293 B.C.E), tendo sido reconhecido como o primeiro a consolidar o subcontinente Indiano como um império submetido a um controlo centralizado. É amplamente consensual que Kautyla foi pioneiro em desenvolver uma "ciência política", a qual representava um grande avanço, quer em relação às preocupações moralistas, espirituais e ascéticas da Filosofia Política indiana, quer em relação às suas especulações religiosas, as quais tinham sido até então dominantes. Kautyla esbateu a distinção

\footnotetext{
* Student of MPhil in International Relations, University of Oxford, United Kingdom.

** Student, M.A. Political Science, University of Delhi, India.
} 
entre moralidade e utilidade política. Muita da teoria política tradicional continua a ignorar o contributo de Kautyla relativamente à a moralidade na realpolitik e a sua persistente influência em sociedades não ocidentais. O seu tratado representa uma via significativa para explorar os dilemas relacionados com a procura ativa de finalidades éticas, sem perder de vista os imperativos atinentes ao pragmatismo politico - uma preocupação que se manteve até aos dias de hoje.

Palavras-chave: Kautilya, Arthashastra, não-ocidente, ciência política, pragmatismo político, ética.

\section{Introduction}

The realm of political philosophizing and practice is inherently replete with certain conundrums. One of the fundamental dilemmas which has puzzled thinkers across centuries has been the perceived dichotomy between political pragmatism on the one hand and ethical considerations on the other. In the past, these two aspects have usually been viewed as mutually exclusive, that is, one has to be/can be obtained at the expense of the other. In practice, this took the form of creating a hierarchy. Opposing sides would either try to elevate political pragmatism over morality; or portray ethics as a higher order of operation thereby relegating practical politics to a lower level of consideration. This often results in straitjacketing both into non-permeable moulds. What happens in such a case is that a relationship and interaction between the two is not only constricted, rather it is disregarded as a possibility. In Western political philosophical tradition for instance, Plato's concept of politics rests on a thoroughly ethico-moral foundation. The Philosopher King was to embody the highest virtues that would set him apart from the ordinary masses. Hence, to think about and to practise politics would put high moral demands on the thinker/practitioner. The evolution of western political philosophy embarked upon a new track which emerged during a period of flux, as embodied by the Renaissance. Niccolò Macchiavelli controversially revolutionised the idea of morality by demarcating an amoral (distinct from immoral) practice of politics to which universal standards of morality are not seen to be applicable.

\section{Political Philosophy And The Non-West}

Beyond the West, debates regarding the relationship between morality and politics have been an integral part of philosophical deliberations. However, given the Eurocentrism of political philosophy, where mostly Western thinkers 
and thought traditions have been accorded primacy, such non-Western deliberations and interventions have often been ignored or sidelined. This omission has significant implications for the theory and practice of politics. Postcolonial scholars have been committed to engaging with "universals" such as a universal conception of man and the universal ideals of morality that are seen to emerge from there. This concept of universal becomes problematic because such "universals" are mostly based on European Enlightenment traditions that do not necessarily reflect the notions of the individual and structures of society and polity prevalent in the non-West. Also, to assume that questions on morality in politics as well as the explanations put forward, have originated in Europe is to fall into the trap of a form of thinking which can be simplistically summed up as "first in the West, then elsewhere" (Chakravarty, 2007). In fact, according to Arnold Toynbee, most of the world's civilisations, have been non-Western. Three of the five surviving civilizations- the Islamic, the Hindu, and the Far Eastern-are non-Western, and another-the Orthodox Christian-has absorbed many nonWestern characteristics (Palmer, 1955). India holds a significant place in the enduring struggle between the East and the West, the reason being that India has been a meeting ground for many different cultures and civilizations. While the Western impact on Indian political thought has been great, India's contribution to Western political thinking is much greater than is generally realized. In a different but relevant context, John A. Lukacs wrote, "For the West can interpret the West; it can only describe the East (Lucaks, 1953). Hence, it is important to critically move beyond such a Eurocentric bias and incorporate these voices within the ambit of political and moral philosophizing because they not only open up new avenues of deliberation but also provide the possibility of alternative answers to existing perennial questions. Indian philosophical thought has often been characterized as being preoccupied with spiritual, metaphysical and theological concerns. This is a misconception; because to have survived this long as a civilization, practical issues and concerns necessarily have had to be very much a part of the key Indian texts and discourses. This is evidenced by the texts of the Arthashastra tradition that this paper seeks to discuss. This tradition more or less borrowed its epistemology from the philosophy of Lokayata. Lokayata philosophy did not believe in concepts like rebirth, Karma , existence of God, caste system and divinity of the Vedas because their efficacy could not stand the 
test of reason and they were not amenable to sense perception. They argue that this world is developed due to combinations of different human actions and efforts; and there is no omnipotent divine agency influencing it. This argument giving primacy to human Reason over divine predetermination was one of the most prominent features of the European Enlightenment. This example illustrates the prejudice that guides the first-in-the-West-then-the-rest ethnocentric understanding of certain core tenets and assumptions underlining political philosophy.

This argument is also important to take into cognizance because when we talk about morality, we have to recognize that morality does not take shape in a vacuum. Morality is essentially derived from socio-cultural, historical norms and ethos, and is very context-specific. This argument is given shape in the theory of 'ethical relativism' which holds morality to the norms of one's culture; that is, whether an action is considered right or wrong depends upon the moral norms of the society in which it is practiced (Brecht, 1959). What is often portrayed as universal is in fact reflective of one specific socio-cultural context which excludes many others. Within the Indian philosophical tradition itself, different strands of views pertaining to the relationship between ethics and politics as well as the role of morality in politics have been articulated across centuries.

\section{Kautilya And The Contingency Of Morality}

Kautilya's Arthshastra is considered a classic in the illustrious Arthashastra tradition of Indian political philosophy. Kautilya was the key adviser to and the chief architect of the strategy undertaken by the Indian king Chandragupta Maurya (c. 317-293 B.C.E.). Chandragupta Maurya defeated the tyrannical Nanda kingdom and also stopped the advance of Alexander the Great's successors, thereby uniting most of the Indian subcontinent in an empire for the first time. Kautilya - sometimes called chancellor or prime minister to Chandragupta - , composed his Arthashastra to show a wise king how to defeat his enemies and rule on behalf of the general good. R. P. Kangle translates the word Arthashastra as "science of politics," a treatise to help a king in "the acquisition and protection of the earth." Others translate Arthasastra in slightly different ways: A. L. Basham says it is a "treatise on polity," Kosambi emphasizes the economic importance of the word in calling it a "science of material gain," and 
G. P. Singh labels it a "science of polity." Kautilya claimed to be putting forth what Heinrich Zimmer rightly calls "timeless laws of politics, economy, diplomacy, and war" (Zimmer, 1967).

According to Kautilya, the state, which he sees as being embodied in the position of the King; , has both a negative and positive function. The negative and positive functions of the state have generally been classified within Hindu philosophy as Danda and Dharma. Danda incorporates the punitive measures adopted and meted out by the King for the orderly maintenance and preservation of worldly life in an otherwise violent state of nature characterised by the concept of Matsya-nyaya (law of the fish where in a situation of anarchy and lawlessness, the bigger fish prey upon the smaller ones). The positive function of the state is to ensure the fullest welfare of the people by upholding the principle of Dharma. Dharma here is seen to mean righteous action and performance of ethical duties. Interestingly, in the 'Shantiparva', the relativistic nature of dharma is clearly brought out wherein it is stated that when it is dangerous to speak the truth, untruth should be spoken. One should first understand circumstances under which he has to act- he should act unrighteously if it helps the course of dharma. Therefore, to protect Dharma, we should behave unrighteously with unjust people and righteously with just people. "Ethics had not assumed in Hindu thought the theoretically independent character that it did at the hands of western writers" (Verma, 1959). In his account, Kautilya shows not the least awareness of an existing dichotomy between politics and ethics, and in fact, takes the whole gamut of life within the political system into his account. In reading his Arthasastra, we find no moral considerations other than a king doing what is right for his own people. For instance, Kautilya's ideal King would have no moral qualms about breaking obligations or trust when it came to alliances in foreign policy: "That ally who might do harm or who, though capable, would not help in times of trouble, he should exterminate him, when trustingly, he comes within his reach." Kautilya also sought to take a nation trying to remain neutral or "indifferent" and secretly provoke war between that nation and a neighbouring kingdom, until the neutral nation sought his help. Then Kautilya's king could “place him under (his) obligations.” Kautilya's ideal King in pursuit of preserving and consolidating the welfare of his own state and people, would take steps such as- commanding secret agents to declare that the Regent of the king is about to 
take power, while the agents kill leaders at night and blame the murders on the Regent of the enemy king; use secret agents in the countryside to sow the seeds of discontent and instigate protests against the oppression of the enemy king's bureaucracy and kill agents of the king hoping to start a revolt. Even when talking about a King's commitment to the welfare of his people, Kautilya appealed to justifications which have essentially pragmatic underpinnings. Kautilya urged the king to be popular with the people and rely on the countryside. "If weak in might, [a king] should endeavour to secure the welfare of his subjects. The countryside is the source of all undertakings; from them comes might." The king's power, for Kautilya, is in the end tied to the power and popular energy of the people, without which a king can be conquered, for "not being rooted among his subjects, [a king] becomes easy to uproot." A righteous king should intervene in the kingdom of a tyrannical king who has weak roots in his populace. This intervention is not only to liberate oppressed masses but here morality is something advantageous and in one's self-interest.

Kautilya made a distinction between morality of the ruler and the ruled, and put the ruler above the ordinary canons of morality. He avoided discriminating between good and evil, and writing from the standpoint of the ruling elite, he confined his interests almost entirely to the affairs of State and man's political behaviour: that is, maintenance and enlargement of power. In this quest for power, Kautilya prescribes various tactics for the king to adopt, which, while ostensibly might seem 'unethical', when perceived from the larger end-goal, can be justified for its ethical political ends.

Kautilya stated that the king should be ready to use almost any means of violence in fighting a war; however, the violence should be directed towards the leaders of the opposing kingdom and not towards the ordinary people. In the pursuit of this power struggle, he discussed at length different means to be adopted by the king to attain victory against an enemy king, which included detailed accounts on how to employ poison, how to assassinate a king, how to arrange for spies and secret agents, how to "sow discord" and to foment and inflame "mutual enmity, hatred, and strife", how to spread disinformation or propaganda, et al. 
For example, on the topic of employing poison, Kautilya advised that while "giving unadulterated wine to the army chiefs, [the secret agent] should give them (wine) mixed with poison when they are in a state of intoxication.” Whereas Kautilya did suggest that an army laying siege to a fort try to "defile the water," this measure seems designed to make those in the fort surrender from illness, not to kill everyone in the fort.

While addressing the question of how to assassinate a king Kautilya suggests hiding "inside the image of a deity or a hollow wall" and emerging at night, making something heavy fall on the king, or using women as secret agents to "drop on him serpents or poisonous fire and smoke." In short, Kautilya prescribed the use of any possible means to assassinate an enemy king-drown him, burn him with fire, suffocate him with smoke, or even use crocodiles as assassins, not to mention employing women and children as poison-givers. By prescribing such tactics, Kautilya's Arthashastra contrasted the prescriptions laid down in the Dharmasutras ${ }^{1}$ where the authors directed that a king should not "strike with barbed or poisoned weapons".

Aside from assassination, another method used to defeat an enemy without full-scale battle was to arrange for the enemy to quarrel and fight among itself. Kautilya believed that the promise of power has the potential to ignite quarrels among high officers or officials. Therefore, as a means to acquire greater power he discusses the need and way to employ spies and secret agents. For example, an elaborate account is provided in one of the passages of the Arthashastra, in which Kautilya details on how one should arrange for a secret agent, disguised as an astrologer, to tell a high officer that he has all the marks of a king, and similarly arrange for a female secret agent, the wife of this officer, to complain that the king wants to keep her in his harem. A third secret agent who is a cook or a waiter should lie, saying that the king has ordered him or her to poison the high officer. "Thus with one or two or three means," according to Kautilya, the king "should incite the high officers one by one to fight or desert" the enemy king.

\footnotetext{
${ }^{1}$ The Dharmasutras is a genre of Sanskrit texts, and refers to the treatises of Hinduism on Dharma, dating back to $1^{\text {st }}$ millennium BCE. The texts include discussion of ashrama (stages of life), varna (social classes), purushartha (proper goals of life), personal virtues and duties such as ahimsa (non-violence) against all living beings, rules of just war, and other topics.
} 
In a discussion about sowing dissensions among oligarchies, Kautilya suggested that "assassins should start quarrels by injuring objects, cattle or men at night," "should stir up princelings enjoying low comforts with (a longing for) superior comforts," and "should start quarrels among the followers of the chiefs in the oligarchy by praising the opponents in brothels and taverns." The goals were constantly to "sow discord" and to foment and inflame "mutual hatred, enmity and strife." In the same manner, he praised the use of disinformation, propaganda and lies to gain political ends. Disinformation also made the use of religion to strengthen its appeal.

Such advice as stated by Kautilya in clear terms violated the tacit code of war found in the great Indian epics. The assassination of envoys and the use of poison were considered to be against the rules of warfare and thus not honourable. The Laws of Manu says that "Fighting in battle, [the king] should not kill his enemies with weapons that are concealed, barbed, or smeared with poison or whose points blaze with fire." Spies were common in Indian history, but not spies who assassinated enemy officials and started quarrels among enemy leaders. Kautilya overlooked such earlier accounts while formulating his own code of conducting the Arthashastra. He judged the means by the result, and the result he sought was the general good of his kingdom and the welfare of its people. The Arthashastra, in this sense, can be said to be one of the earliest texts to have put into question the unmarked distinction between ethics and politics.

For Kautilya, the end "good" justifies the usage of "bad", if not "evil", means. He, therefore, is highly cautious of the activities to be adopted by a king once he emerges victorious. A conquering king should reassure a defeated people that not much, except their rulers, has changed. The king who has triumphed "should adopt a similar character, dress, language and behaviour (as the subjects). And he should show the same devotion in festivals in honour of deities of the country, festive gatherings and sportive amusements.” The conquering king should show his goodwill toward the defeated by instituting "a righteous custom, not initiated before." While the victorious king is reassuring the general population with generous policies, he must continue to kill anyone who is dangerous and those who are disgruntled: "He should put down by silent punishment those capable of injuring [him] or those brooding on the master's 
destruction."2 The importance attached by Kautilya towards keeping the population satisfied, to the extent of appeasement of the vanquished people, and swiftly rooting out the disgruntled elements of the society is a political goal in itself through which the king can seek to further his power. Thus, Kautilya puts forth a unique combination of both the positive and negative aspects of political practice, that is, Dharma and Danda respectively, for a just and powerful rule by the king over his people.

\section{Conclusion}

In this paper, we do not claim that the solution Kautilya offered in navigating through the conundrum between morality and politics is the only correct or right approach. What we have intended to highlight is that Kautilya started the conversation by acknowledging the tensions that might crop up while trying to locate the role of morality (if there was any) within politics. His position was a significant break from the earlier traditions of Indian philosophy which put forward predominantly moralistic and normative injunctions. Kautilya was writing at a time of great political churning- the existing ruling order was crumbling from within while conquerors were hounding at the doorsteps. In such a situation, Kautilya responded to these challenges by not just discarding morality as irrelevant to practical political needs, but reconfigured morality to strengthen practical politics itself.

Morality in politics is often seen as a liability- something which hinders effective results in the practical world of real life politics. What such an assumption fails to take into account is that many of the issues that politics faces and has to respond to, are inherently moral in nature. To try and evade them by putting forward so-called "objective" solutions does not do justice to the gravity of those problems. The goal should not be to put morality and politics within separate air-tight containers to be brought out together as and when convenient. There is rather, a need to recognize that morality and politics coexist, even if we close our eyes to the fact. This is not to advocate a homogenous, static idea of morality to be imposed by the majority on the others. What this paper has sought to demonstrate is that what is morality and what is politics themselves need to be

\footnotetext{
${ }^{2}$ Kautilya, Artha's-astra, 13.5.17: 492.
} 
constantly examined, keeping in mind contemporary contingencies and differential contexts while we talk about the role of morality in politics.

\section{References}

Ali, S. (2006). Kautilya and the Concept of Good. The Indian Journal of Political Science, 67(2), 375-380.

Boesche, R. (2003). Kautilya's Arthasastra on War and Diplomacy in Ancient India. The Journal of Military History, 67(1): 9-37.

Chakrabarty, D. (2007). Provincializing Europe. Princeton, NJ: Princeton University Press.

Chousalkar, A. (1981). Political Philosophy of Arthashastra Tradition. The Indian Journal of Political Science, 42(1): 54-66.

Kautilya (1992). The Arthashastra: Part II of The Kautilya Arthashastra (R.P. Kangle, $\quad$ Ed. and Trans.). Delhi: Motilal Banardisass, 1992.

Kosambi, D. D. (1994). The Culture and Civilisation of Ancient India. Delhi: Vikas Publishing House.

Krishna Rao, M. V. (1958). Studies in Kautilya. New Delhi: Munshi Ram Manohar Lal.

Mercer, M. D. (1993). On a Pragmatic Argument against Pragmatism in Ethics. $\quad$ American Philosophical Quarterly, 30(2): 163-173.

Palmer, N. D. (1955). Indian and Western Political Thought: Coalescence or Clash? The American Political Science Review, 49(3): 747-761.

Prasad, D. (1978). Politics and Ethics in Kautilya's. The Indian Journal of Political Science, 39(2): 240-249.

Singh, G. P. (1993). Political Thought in Ancient India. New Delhi: D.K. Printworld.

Verma, V. P. (1959). Hindu Political Thought and Its Metaphysical Foundation. (2nd ed.). New Delhi: Motilal Banarasidas. 
Political pragmatism and ethics in Kautyla's Arthashastra: contradiction or complementarity

Zimmer, H. (1967). Philosophies of India. Princeton, N.J.: Princeton University Press. 